\title{
Kajian Jenis dan Bentuk Insentif serta Kemudahan Penanaman Modal Pada Sasaran Wilayah Investasi (Studi Kasus: Kabupaten Banyumas)
}

\author{
Titin Andini dan Samsul Ma'rif \\ Departemen Perencanaan Wilayah dan Kota, Fakultas Teknik \\ Universitas Diponegoro \\ e-mail: titinandini65@gmail.com
}

\begin{abstract}
Abstrak-Pertumbuhan ekonomi berkelanjutan dalam jangka waktu panjang menjadi salah satu tujuan dari pembangunan di Kabupaten Banyumas, salah satu bagian dari berbagai aspek krusial dalam pembangunan daerah diantaranya merupakan dengan meningkatkan iklim investasi. Akan tetapi pada proses pelaksanaannya, pembangunan antar daerah satu dengan yang lainnya di Kabupaten Banyumas memiliki progres yang berbeda serta dapat menimbulkan ketimpangan dalam pembangunan. Berbagai upaya yang telah dilakukan oleh pemerintah daerah Banyumas dalam mempromosikan daerahnya dengan tujuan untuk menarik minat investor, menaikan pendapatan daerah, dan pemerataan pembangunan. Sehingga dari fenomena ini diperlukannya instrumen untuk mendorong iklim investasi yaitu kajian pemberian insentif serta dipermudahnya penanaman modal di Kabupaten Banyumas. Tujuan dari studi ini adalah untuk menetapkan prioritas kriteria dan alternatif dalam peningkatan iklim investasi dan pemerataan pembangunan Kabupaten Banyumas. Pada riset ini digunakan metode Tipologi Wilayah dan Analytical Hierarchy Process (AHP) untuk mencari prioritas jenis dan bentuk insentif yang akan pada sasaran wilayah investasi Banyumas. Data diperoleh dari form kuesioner dengan 25 responden yang mendalami bidang penelitian ini. Hasil penelitian menyimpulkan bahwa setiap tipologi wilayah investasi akan memiliki karakteristik jenis serta bentuk insentif dan kemudahan penanaman modal yang berbeda, sebagai strategi penanganan wilayah investasi. Kemudahan akses pelayanan merupakan prioritas utama pada wilayah maju pesat. Wilayah potensial memiliki prioritas utama yaitu bantuan keuangan, bantuan keuangan disini lebih mengarah pada bantuan kepada pemberian keringanan, pengurangan, atau pembebasan pajak maupun retribusi daerah. Bantuan dalam menyediakan fasilitas dan utilitas merupakan bagian dari insentif dan kemudahan yang cocok diterapkan di wilayah berkembang. Sedangkan pada wilayah terbelakang bentuk insentif yang tepat adalah bantuan keuangan. Bantuan keuangan disini mengarah kepada bunga pinjaman rendah, pemberian kompensasi, dan bantuan fasilitas untuk kegiatan pelatihan usaha mikro, kecil, atau koperasi. Hal ini dikarenakan wilayah terbelakang memiliki bidang usaha dominan adalah pertanian, peternakan dan UMKM pengolahan makanan.
\end{abstract}

Kata Kunci-Analytical Hierarchy Process, Insentif, Investasi, Kemudahan Penanaman Modal, dan Tipologi Investasi

\section{PENDAHULUAN}

$\mathrm{P}$ embangunan ekonomi merupakan serangkaian aktivitas yang bertujuan dalam mewujudkan pengembangan kegiatan ekonomi dan kualitas hidup masyarakat [11]. Menurut
Todaro (1995) dalam Belascu \& Horobet (2015) Wujud dari keberhasilan pembangunan ekonomi ditandai dengan kemampuan yang berkembang untuk mencukupi kebutuhan dasarnya, peningkatan harga diri manusia, peningkatan kemampuan menentukan sebagai bagian hak asasi manusia. Sehingga muncul berbagai upaya dilakukan oleh pemangku kepentingan guna meningkatkan pembangunan ekonomi.

Pembangunan ekonomi daerah adalah salah satu bentuk dari upaya yang telah disebutkan diatas yaitu pemerintah daerah bersama dengan masyarakat mengelola sumber daya wilayah dan membentuk kemitraan bekerja sama menciptakan lapangan kerja baru di dalam daerah tersebut [21]. Setiap program pembangunan ekonomi daerah sama-sama memiliki tujuan dalam mewujudkan meningkatnya kapasitas dan variasu lapangan kerja daerah [7]. Selain memiliki tujuan dalam upaya pembangunan ekonomi juga harus memiliki strategi, hal ini dikarenakan untuk memberikan arah jangka panjang terhadap pembangunan ekonomi tersebut. sehingga pembangunan ekonomi bukan hanya hal yang dilakukan untuk mencapai tujuan tetapi juga sebagai alat dalam menjalankan tujuan tersebut agar memiliki manfaat jangka panjang.

Strategi Pengembangan ekonomi antar wilayah satu dengan wilayah lain akan memiliki jenis, karakteristik, dan cara yang berbeda [23]. Upaya yang dilakukan dalam pengembangan wilayah tergantung pada potensi dan kebutuhan setiap wilayah. Sehingga diperlukan kajian terhadap karakteristik yang melekat dalam suatu wilayah, hal ini berguna untuk membedakan konsep dan pengambilan keputusan yang akan diterapkan dalam pengembangan ekonomi.

Adanya perbedaan strategi pengembangan wilayah menyebabkan perbedaan kemajuan perekonomian di dalam suatu daerah. Perbedaan strategi ini diterapkan berdasarkan potensi dan masalah wilayah tersebut, dengan kata lain pengembangan di setiap wilayah pastinya akan memiliki karakter tersendiri [10]. Sehingga dari hal ini akan muncul kawasan dengan perkembangan ekonomi yang prospektif dan wilayah kawasan dengan perkembangan ekonomi yang kurang baik atau non-prospektif.

Perkembangan ekonomi dipengaruhi oleh 4 aspek yaitu investasi, konsumsi, pembiayaan pemerintah, serta neraca perdagangan [11]. Apabila neraca perdagangan menyebabkan perlambatan dalam perekonomian, maka pada saat itulah investasi menjadi komponen krusial untuk meningkatkan perekonomian [25]. Sehingga kunci dalam pengembangan perekonomian suatu daerah adalah dilihat dari iklim investasi yang masuk ke dalam daerah tersebut. 
Investasi atau sering disebut penanaman modal sendiri merupakan suatu kegiatan yang mampu merubah kondisi perekonomian secara cukup luas yaitu meningkatkan besarnya produk jasa atau barang, menciptakan nilai tambah, tenaga kerja, meningkatkan pendapatan masyarakat daerah, serta ikut berfungsi menjadi sumber pendapatan daerah yakni berupa retribusi dan pajak. Kegiatan penanaman modal mampu meningkatkan kapasitas ekonomi daerah. Selain itu ia juga secara langsung menumbuhkan tingkat kesejahteraan masyarakat umum dan akan bermanfaat dalam meningkatkan kondisi fiskal daerah. Penanaman modal ditujukan untuk meningkatkan produktivitas agregat, sehingga memerlukan dukungan investasi kondusif dengan kepastian, kestabilan dan keamanan, stabilitas makro ekonomi (inflasi, kurs, suku bunga, dll), penyediaan infrastruktur, dan setiap daerah harus menjamin kerjasama sinergis antar daerah. Sehingga kegiatan penanaman modal atau investasi sangat erat kaitannya untuk mencapai pembangunan ekonomi daerah.

Pemerintah Provinsi Jawa Tengah menyatakan Kabupaten Banyumas adalah bagian dari target pengembangan kawasan investasi di Jawa Tengah. Hal ini dikarenakan Kabupaten Banyumas memiliki peluang besar dalam pengembangan investasi khususnya manufaktur dan pariwisata. Selain itu data pertumbuhan PDRB Kabupaten Banyumas tergolong tinggi yaitu $>6 \%$ selama 7 tahun berturut turut. Angka ini juga diatas rata-rata PDRB cakupan wilayah BARLINGMASCAKEB.

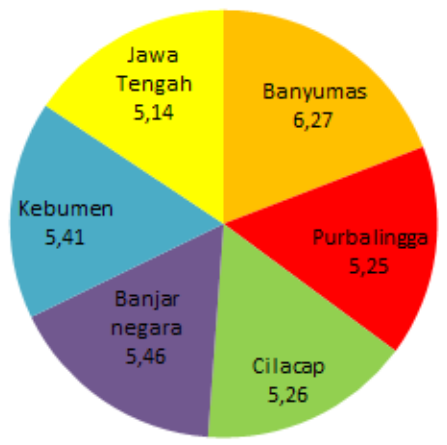

Gambar 1. PDRB Kab.Banyumas Tahun 2015-2019

Upaya untuk mendorong perkembangan investasi Kabupaten Banyumas dengan memanfaatkan potensi yang telah dijelaskan diatas, maka diperlukannya instrumeninstrumen yang baik agar perkembangan investasi dan pembangunan ekonomi berkembang lebih pesat. Sehingga dapat disimpulkan bahwa aktivitas menanam modal telah menjadi penyelenggaraan perekonomian dan merupakan upaya meningkatnya ekonomi daerah. Aktivitas penanaman modal berperan untuk meningkatkan pemasukan dan penyerapan tenaga kerja daerah. Sehingga diperlukannya cara atau upaya yang dapat meningkatkan iklim investasi Kabupaten Banyumas.

\section{KAJIAN LITERATUR}

\section{A. Penanaman Modal atau Investasi}

Pengembangan kegiatan penanaman modal menurut perspektif berkembangnya daya saing daerah. Daya saing daerah merupakan kemampuan daerah pada bidang ekonomi sehingga tercapai peningkatan dan keberlanjutan [20]. Daya saing daerah mengukur kemampuan daerah mendapatkan pemasukan dan lapangan kerja yang besar. Sehingga pengembangan kawasan yang ditujukan untuk kegiatan penanaman modal bertujuan untuk meningkatkan daya saing daerah.

Pengembangan kawasan investasi dibedakan berdasarkan sektor seperti industri, pariwisata, permukiman, pertambangan dan penggalian, perdagangan dan jasa, pertanian dan perikanan. Selain itu penentuan lokasi pengembangan kawasan investasi didasarkan peluang pengembangan dan permasalahan daerah yang disertai dengan tinjauan kebijakan terkait. Sehingga dalam pengembangan kawasan investasi diperlukan strategi yang berbeda, dikarenakan sektor yang dikembangkan untuk investasi dalam satu wilayah berbeda.

\section{B. Tipologi Wilayah Investasi}

Pada sasaran wilayah pemberian insentif dan kemudahan penanaman modal akan dikelompokan berdasarkan indikator tertentu. Untuk mengetahui wilayah-wilayah yang menjadi sasaran pemberian insentif dan kemudahan penanaman modal dilakukan menggunakan metode tipologi kawasan. Tipologi merupakan kajian pengelompokan sesuatu kepada kategori yang telah ditentukan [15]. Dengan kata lain karakteristik tertentu atau merujuk pada kelompok tertentu.

Indikator ketidakmerataan wilayah merupakan tingkat kualitas pendidikan, kesejahteraan penduduk, pola penyebaran dan konsentrasi investasi, penyediaan fasilitas dan utilitas. Indikator kesenjangan dapat dibedakan menjadi fisik, ekonomi, dan sosial. Fisik dengan adanya fasilitas kesehatan, pendidikan dan perekonomian. Ekonomi terkait dengan kemampuan penduduk berdasarkan kesejahteraan keluarga. Sosial terkait dengan jumlah hingga kualitas penduduk menurut pendidikan.

Beberapa faktor utama penyebab terjadinya disparitas antar wilayah sebagai berikut:

- Perbedaan demografis

- Konsentrasi kegiatan ekonomi wilayah

- Mengalokasikan investasi

- Ketersediaan infrastruktur

- Rendahnya mobilitas produksi

- SDA antar wilayah berbeda

- Pola perdagangan antar wilayah

Tipologi wilayah investasi digolongkan menjadi 4 yaitu wilayah maju pesat, wilayah potensial, wilayah berkembang dan wilayah terbelakang. Masing-masing klasifikasi wilayah tersebut memiliki karakteristik tersendiri sesuai dengan variabel yang akan dinilai. Sehingga terdapat perbedaan strategi dalam penanganan di masing-masing klasifikasi.

\section{Kajian Pemberian Jenis dan Bentuk Insentif serta}

Kemudahan Penanaman Modal

Salah satu strategi pengembangan kawasan investasi khususnya untuk kawasan non prospektif atau dengan pertumbuhan ekonomi yang lambat adalah dengan pemberian insentif dan kemudahan penanaman modal. Insentif dan kemudahan penanaman modal merupakan subsidi yang diberikan untuk mempengaruhi lokasi investasi baru [35]. 
Pemberian insentif memiliki tujuan guna meningkatkan adanya investasi baru atau mempertahankan fasilitas yang telah ada di wilayah tersebut [12], Perspektif terkait insentif ini dipandang sebagai dorongan dari pihak yang berkuasa yaitu pemerintah untuk memajukan suatu wilayah [28].

Tinjauan terhadap Peraturan Daerah Banyumas No. 2 Tahun 2013 lebih tepatnya dalam Pasal 23 Ayat (2) dan Ayat (3), dimana pada ayat tersebut memuat 4 bentuk insentif dan 5 bentuk kemudahan penanaman modal. Bentuk insentif maupun kemudahan yang di muat dalam Perda ini kurang variatif. Berikut merupakan detail dari bentuk insentif dan kemudahan penanaman modal pada Perda No. 2 Tahun 2013:

\section{Pasal 23}

(2) Bentuk Insentif yang dapat diberikan oleh Pemerintah Daerah Antara Lain:

a. Pengurangan, Keringanan, Atau Pembebasan Pajak Daerah;

b. Pengurangan, Keringanan, Atau Pembebasan Retribusi Daerah;

c. Pemberian dana simultan; dan/ atau

d. Pemberian Bantuan Modal

(3) Bentuk Kemudahan yang dapat diberikan oleh Pemerintah Daerah Antara Lain:

a. Data Informasi Peluang Penanaman Modal;

b. Penyediaan Sarana dan Prasarana;

c. Penyediaan Lahan dan Lokasi;

d. Pemberian Bantuan Teknis; dan/ atau

e. Percepatan proses perizinan secara paralel

Pada peraturan di atas juga belum adanya muatan yang membahas mengenai jenis insentif maupun kemudahan penanaman modal. Selain itu Kabupaten Banyumas juga belum mempunyai Peraturan Daerah maupun Peraturan Bupati yang secara khusus membahas pemberian insentif dan kemudahan penanaman modal. Sehingga dari fenomena tersebut dapat disimpulkan bahwa faktor yang menghambat kegiatan investasi adalah belum adanya kebijakan terkait insentif.

\section{METODE PENELITIAN}

Penelitian ini bertujuan untuk mengkaji bentuk dan jenis pemberian insentif dan kemudahan penanaman modal sebagai langkah peningkatan iklim investasi di Kabupaten Banyumas. Metode menggunakan metode Tipologi Wilayah Investasi dan Analisis Hirarki Proses. Kedua metode tersebut akan dikompilasi menjadi satu, sehingga menghasilkan karakteristik strategi atau penanganan yang tepat pada masing-masing wilayah investasi.

\section{A. Teknik Pengumpulan Data dan Penentuan Narasumber}

Penentuan sasaran wilayah investasi dilakukan dengan teknik pengumpulan data sekunder, seperti kesesuaian lahan, kemampuan lahan, sebaran potensi wilayah, dan sebaran kegiatan investasi. Memperoleh data dari dokumen referensi terkait kebijakan pengadaan insentif dan upaya memudahkan adanya penanaman modal. Langkah selanjutnya adalah melakukan diskusi bersama pengambil keputusan terhadap kriteria yang menjadi pertimbangan pemberian bentuk dan jenis Insentif maupun kemudahan penanaman modal pada sasaran wilayah investasi melalui kuesioner. Teknik pengumpulan data sebagai berikut:

1) Searching

Searching dengan mencari data di web search, pencarian ini adalah table look-up atau store and retrieval information, sehingga diketahui sumber daya alam yang ada di Kabupaten Banyumas, ketersediaan infrastruktur, dan kondisi penanaman modal Banyumas. Kegiatan observasi lapangan dilakukan untuk mengumpulkan data mengenai kajian yang digunakan untuk pengembangan investasi dan bentuk serta jenisyang akan diberikan. Data sekunder dengan mengkaji dokumen yang didapatkan melalui survei ke instansi berupa Dinas Penanaman Modal dan Pelayanan Terpadu Satu Pintu, Badan Pusat Statistik dan lembaga terkait lainnya.

2) Kuisioner

Kuisioner dilakukan dengan cara mengajukan kompilasi pertanyaan tertulis yang telah dipersiapkan kepada narasumber untuk dijawab (Sugiyono, 2013). Pertanyaan yang diajukan biasanya berupa pertanyaan tertulis yang nantinya akan diisi oleh responden. Kuesioner yang telah dilengkapi diberikan kembali kepada peneliti. Kuesioner digunakan untuk mengumpulkan data secara efisien dan efektif. Dalam pengumpulan data menggunakan kuesioner variabel yang digunakan telah jelas serta telah terdapat pilihan jawabannya. Dalam penggunaan kuesioner untuk populasi yang besar maka dapat digunakan sampel yang dapat mewakili responden secara umum. Kuesioner digunakan dalam penelitian untuk mendapatkan informasi mengenai bentuk dan jenis insentif dan upaya memudahkan kegiatan penanaman modal yang diberikan berdasarkan jawaban responden, yaitu Pemerintah, Badan Usaha, ataupun masyarakat yang memiliki usaha di daerah tersebut.

3) Telaah Dokumen

Pengumpulan data sekunder dengan telaah dokumen dari instansi terkait. Pada studi ini, kajian pada dokumen instansi ditujukan kepada Dinas Penanaman Modal dan Pelayanan Terpadu Satu Pintu untuk mengetahui kondisi dan perkembangan investasi yang masuk di Kabupaten Banyumas dan juga bagaimana realisasi dari investasi tersebut. Selain itu telaah dokumen dilakukan untuk mengetahui jenis dan bentuk insentif dan kemudahan yang biasa diberikan di daerah.

Teknik sampling dengan purposive sampling yaitu sampel dipilih dari elemen populasi secara acak dan setiap individu dari populasi memiliki hak yang sama untuk dapat dijadikan sebagai sampel. AHP dapat digunakan untuk kepentingan individu ataupun dipakai dalam sebuah kelompok dengan memakai kuesioner yang sama. Hal ini dikarenakan ketidak jelasan kriteria expert dan sering timbulnya keragu-raguan akan kualitas seorang expert, membuat proses pengambilan keputusan dengan metode AHP ditetapkan lebih dari satu expert. Selain untuk mengurangi terjadinya ketidak jelasan kriteria dan kualitas expert dan untuk mendapatkan persepsi dari berbagai sudut pandang maka responden untuk mengisi kuesioner persepsi AHP dikategorikan menjadi 2 sudut 
pandang yaitu dari sudut pandang pemberi kebijakan (dinas) dan yang menerima kebijakan (pengusaha). Dari sudut pandang pemberi kebijakan ditetapkan sebanyak 5 lembaga/ instansi secara Judgment.

Terdapat sedikit kendala dalam penentuan expert dari klasifikasi pengusaha, hal ini dikarenakan situasi dan kondisi terdampak covid-19 yang mengakibatkan narasumber atau expert tidak mau ditemui. Sehingga peneliti mengambil kebijakan sebagian penentuan expert ini berdasarkan rekomendasi Kadin dan secara accidental sampling.

\section{B. Tipologi Wilayah}

Pada metode Tipologi Wilayah Investasi dilakukan dengan alat bantu analisis berupa Arcgis dan dilakukan dengan cara weighted overlay pada masing-masing variabel yang telah ditentukan. Sebelum melakukan pembobotan terhadap variabel tersebut harus dilakukan beberapa tahapan, yaitu:

1) Identifikasi karakteristik fisik wilayah

Tabel 1.

\begin{tabular}{ccc} 
& Klasifikasi Fisik Wilayah & \\
\hline \multirow{4}{*}{ Rawan Bencana } & Klasifikasi & Skor \\
\cline { 2 - 3 } & Sangat Tinggi & 5 \\
& Tinggi & 4 \\
& Sedang & 3 \\
& Rendah & 2 \\
\hline \multirow{4}{*}{ Tata Guna Lahan } & Klasifikasi & Skor \\
\cline { 2 - 3 } & Sangat Sesuai & 5 \\
& Sesuai & 4 \\
& Sedang & 3 \\
Kemiringan Lereng & Rendah & 2 \\
\cline { 2 - 3 } & Klasifikasi & Skor \\
\hline & $0-8 \%$ & 5 \\
& $8-15 \%$ & 4 \\
& $15-25 \%$ & 3 \\
& $25-<40 \%$ & 2 \\
Hidrogeologi & $<40 \%$ & 1 \\
\hline & Klasifikasi & Skor \\
\cline { 2 - 3 } & akuifer produktif dengan penyebaran & 5 \\
& luas & 4 \\
& akuifer produktif penyebaran sedang & 4 \\
& Akuifer produktif kecil dan setempat & 3 \\
& daerah air langka & 2 \\
\hline
\end{tabular}

2) Identifikasi potensi pendukung kegiatan investasi

Tabel 2.

Klasifikasi Potensi Pendukung Kegiatan Investasi

\begin{tabular}{ccc}
\hline \multirow{3}{*}{ Jaringan Jalan } & $\begin{array}{c}\text { Klasifikasi } \\
(\mathrm{m})\end{array}$ & Skor \\
\cline { 2 - 3 } & $0-500$ & 5 \\
& $500-1000$ & 4 \\
& $1000-1500$ & 3 \\
& $1500-2000$ & 2 \\
\hline Pasar/ Pusat & Klasifikasi & Skor \\
\cline { 2 - 3 } Perbelanjaan & $0-1000$ & 5 \\
& $1000-3000$ & 4 \\
& $3000-5000$ & 3 \\
Stasiun & $>5000$ & 2 \\
\hline & Klasifikasi & Skor \\
\cline { 2 - 3 } & $0-200$ & 5 \\
& $200-400$ & 4 \\
& $400-1000$ & 3 \\
& $>1000$ & 2 \\
\hline
\end{tabular}

\begin{tabular}{ccc}
\hline & Klasifikasi & Skor \\
\cline { 2 - 3 } Terminal & $0-200$ & 5 \\
& $200-400$ & 4 \\
& $400-1000$ & 3 \\
& $>1000$ & 2 \\
\hline \multirow{4}{*}{ Wisata } & Klasifikasi & Skor \\
\cline { 2 - 3 } & $0-1000$ & 5 \\
& $1000-3000$ & 4 \\
& $3000-5000$ & 3 \\
Pertambangan & $>5000$ & 2 \\
\hline & Klasifikasi & Skor \\
\hline & $0-400$ & 5 \\
& $400-1000$ & 4 \\
& $1000-2000$ & 3 \\
& $>2000$ & 2 \\
\hline
\end{tabular}

3) Identifikasi aktivitas penanaman modal

Tahapan ini dilakukan dengan cara melihat sebaran aktivitas investasi pada setiap kecamatan di Kab. Banyumas. Selain iu juga dilihat dari jumlah realisasi berdasarkan cetak bidang investasi yang masuk. Berikut merupakan peta sebaran dan realisasi investasi Kab. Banyumas:

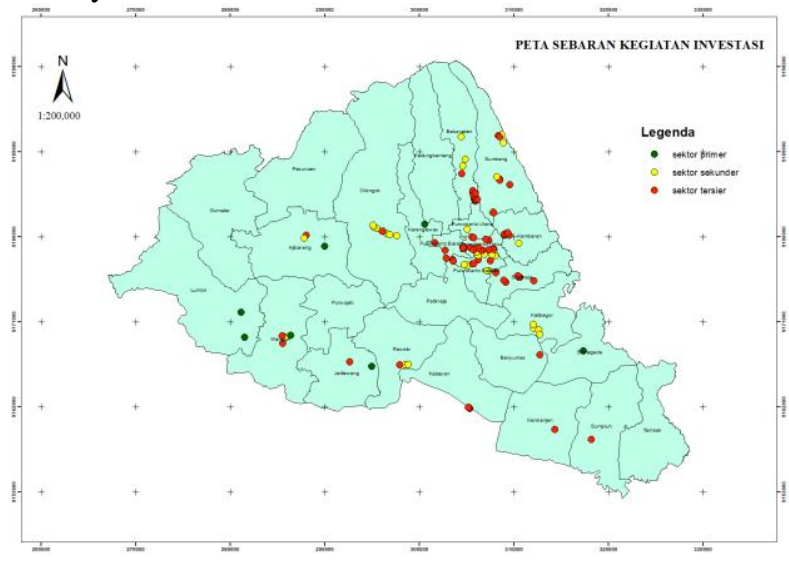

Gambar 2. Peta Sebaran Kegiatan Investasi Kab. Banyumas

Tabel 3.

Realisasai dan Cetak Bidang Investasi

\begin{tabular}{clcc}
\hline No. & Kecamatan & $\begin{array}{c}\text { Cetak Bidang } \\
\text { Dominan }\end{array}$ & $\begin{array}{c}\text { Realisasi } \\
\text { Investasi } \\
\text { (Juta) }\end{array}$ \\
\hline 1. & Lumbir & $\begin{array}{c}\text { Pertanian dan } \\
\text { Peternakan } \\
\text { Pertanian, } \\
\text { Peternakan, dan } \\
\text { Pertambangan }\end{array}$ & $3,485.10$ \\
2. & Wangon & $\begin{array}{c}\text { Pertanian dan } \\
\text { Peternakan }\end{array}$ & $3,59,611.50$ \\
3. & Jatilawang & $\begin{array}{c}\text { Pertaniandan } \\
\text { Peternakan }\end{array}$ & $2,286.60$ \\
4. & Rawalo & $\begin{array}{c}\text { Perdagangan dan } \\
\text { Reparasi }\end{array}$ & $4,975.00$ \\
5. & Kebasen & $\begin{array}{c}\text { Perdagangan dan } \\
\text { Reparasi }\end{array}$ & $1,800.00$ \\
6. & Kemranjen & $\begin{array}{c}\text { Perdagangan dan } \\
\text { Reparasi } \\
\text { Industri }\end{array}$ & $2,650.00$ \\
7. & Sumpiuh & $\begin{array}{c}\text { Pengolahan } \\
\text { Makanan }\end{array}$ & $1,387.50$ \\
8. & Tambak & $\begin{array}{c}\text { Pertanian dan } \\
\text { Peternakan } \\
\text { Industri }\end{array}$ & $124,857.10$ \\
9. & Somogede & $32,204.62$ \\
\hline 10. & Kalibagor & & \\
\hline
\end{tabular}




\begin{tabular}{|c|c|c|c|}
\hline 11. & Banyumas & $\begin{array}{c}\text { Pengolahan } \\
\text { Makanan } \\
\text { Perdagangan dan } \\
\text { Jasa }\end{array}$ & $14,012.30$ \\
\hline 12. & Patikraja & $\begin{array}{c}\text { Perdagangan dan } \\
\text { Jasa }\end{array}$ & $43,180.00$ \\
\hline 13. & Purwojati & $\begin{array}{c}\text { Perdagangan dan } \\
\text { Jasa }\end{array}$ & $2,750.00$ \\
\hline 14. & Ajibarang & $\begin{array}{l}\text { Perdagangan dan } \\
\text { Jasa }\end{array}$ & $2,035.00$ \\
\hline 15. & Gumelar & $\begin{array}{l}\text { Pertanian dan } \\
\text { Peternakan }\end{array}$ & $1,031.07$ \\
\hline 16. & Pekuncen & $\begin{array}{l}\text { Pertanian dan } \\
\text { Peternakan }\end{array}$ & $1,102.45$ \\
\hline 17. & Cilongok & Industri & $11,415.00$ \\
\hline 18. & Karanglewas & $\begin{array}{c}\text { Perdagangan dan } \\
\text { Jasa }\end{array}$ & $36,124.00$ \\
\hline 19. & Kedungbanteng & $\begin{array}{l}\text { Perdagangan dan } \\
\text { Jasa }\end{array}$ & $8,560.80$ \\
\hline 20. & Baturraden & $\begin{array}{c}\text { Perdagangan dan } \\
\text { Jasa }\end{array}$ & $84,527.00$ \\
\hline 21. & Kembaran & $\begin{array}{l}\text { Perdagangan dan } \\
\text { Jasa }\end{array}$ & $58,582.50$ \\
\hline 22. & Sokaraja & $\begin{array}{l}\text { Perdagangan dan } \\
\text { Jasa }\end{array}$ & $118,677.30$ \\
\hline 23. & Sumbang & $\underset{\text { Jasa }}{\text { Perdagangan dan }}$ & $28,364.29$ \\
\hline 24. & Purwokerto Utara & $\begin{array}{l}\text { Perdagangan dan } \\
\text { Jasa }\end{array}$ & $13,100.30$ \\
\hline 25. & $\begin{array}{l}\text { Purwokerto } \\
\text { Selatan }\end{array}$ & $\begin{array}{l}\text { Perdagangan dan } \\
\text { Jasa }\end{array}$ & $309,917.75$ \\
\hline 26. & Purwokerto Barat & $\begin{array}{c}\text { Perdagangan dan } \\
\text { Jasa }\end{array}$ & $106,581.40$ \\
\hline 27. & $\begin{array}{l}\text { Purwokerto } \\
\text { Timur }\end{array}$ & $\begin{array}{c}\text { Perdagangan dan } \\
\text { Jasa }\end{array}$ & $377,487.99$ \\
\hline
\end{tabular}

\section{Analytical Hierarchy Process (AHP)}

AHP termasuk ke dalam model yang dapat mendukung keputusan dengan menguraikan multi faktor atau multi kriteria kompleks menjadi hirarki. Metode ini digunakan untuk menganalisis referensi pilihan bentuk dan jenis insentif dan memudahkan penanaman modal yang akan menjadi tujuan penelitian ini. Berikut merupakan tahapan dalam AHP:

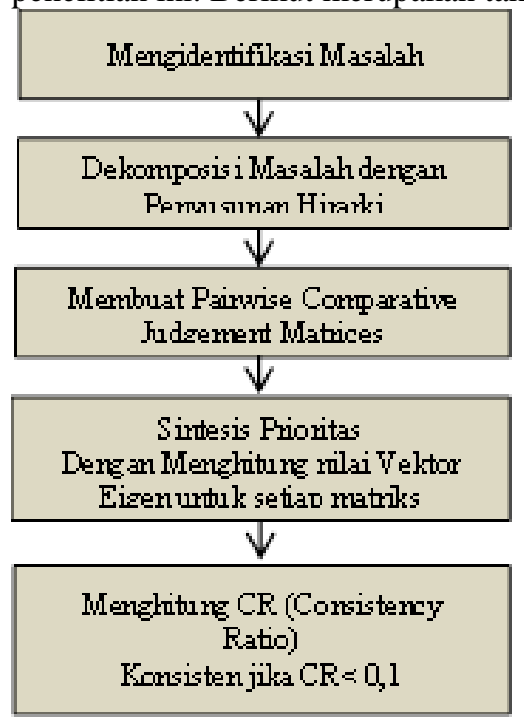

Gambar 3. Tahapan AHP

Berikut merupakan hararki penelitian ini:

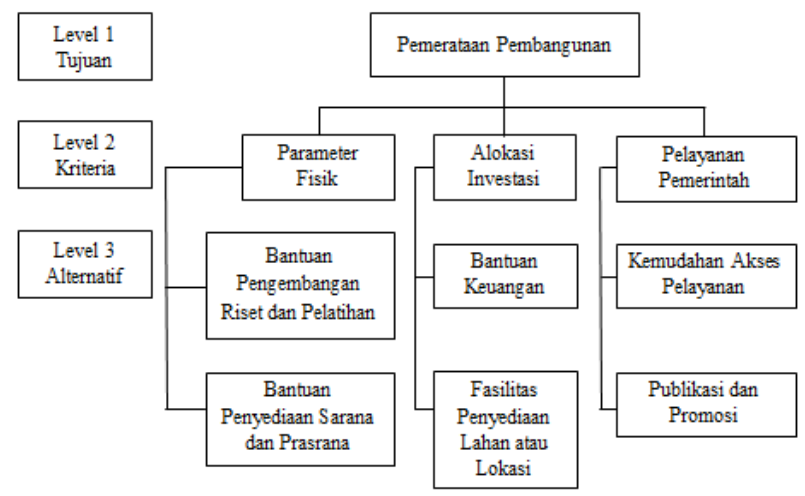

Gambar 4. Hirarki AHP

\section{HASIL DAN PEMBAHASAN}

\section{A. Tipologi Wilayah}

Penentuan tipologi wilayah invetasi Kabupaten Banyumas diperoleh dari hasil perbandingan alokasi investasi dan karakteristik fisik wilayah yang menjadi parameter utama. Pada analisis tipologi invetasi ini akan menghasilkan 4 klasifikasi wilayah berdasarkan jumlah skoring yang telah diberikan sebelumnya. Berikut merupakan tabel diagram klasifikasi wilayah investasi Kabupaten Banyumas:

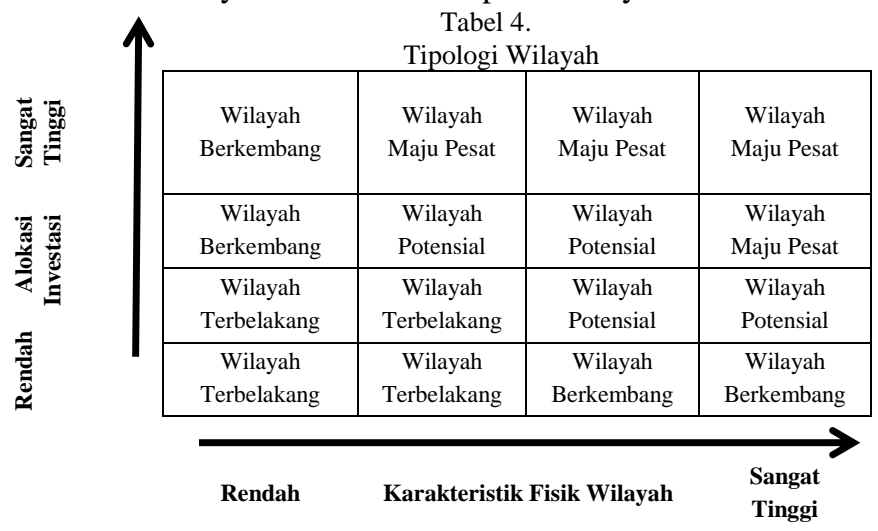

Berdasarkan hasil olahan data kewilayahan klasifikasi wilayah maju pesat adalah wilayah dengan nilai parameter karakteristik fisik wilayah, potensi wilayah dan aktivitas penanaman modal yang sangat tinggi. Hal ini selaras dengan pendapat Pakdeenurit et al (2017) yang menyatakan bahwa wilayah maju merupakan wilayah dengan didukung oleh kelengkapan sarana-prasarana, kondisi geografi yang mendukung, pendapatan wilayah yang tinggi dan mendapatkan perhatian khusus dari pemerintah pusat. Sehingga dapat disimpulkan bahwa wilayah maju merupakan wilayah dengan segala kelengkapan dari berbagai aspek mulai dari fisik sampai kebijakan pemerintah.

Menurut Chander (2012) wilayah potensial merupakan wilayah dengan ciri potensi yang tinggi dan dikatakan wilayah ini sebagai wilayah penghasil. Berdasarkan hasil penelitian wilayah potensial adalah wilayah dengan nilai parameter potensi dan karakteristik fisik yang tinggi sedangkan nilai aktivitas penanaman modal yang masuk cenderung rendah. Sehingga hasil penelitian dan pendapat Chander hampir selaras yaitu wilayah potensial merupakan wilayah dengan karakteristik potensi yang melimpah. 
Wilayah berkembang tapi tertekan menurut hasil pengolahan data adalah wilayah dengan nilai parameter aktivitas penanaman modal yang tinggi sedangkan karakteristik fisik dan potensi yang cenderung rendah. Hal ini diperkuat oleh pendapat Chander (2012) yang menyatakan bahwa wilayah berkembang merupakan wilayah dengan pendapat daerah yang tinggi karena jumlah investasi yang masuk tinggi, akan tetapi wilayah tersebut terhambat oleh keterbatasan pelayanan infrastruktur. Sehingga wilayah berkembang merupakan wilayah dengan jumlah alokasi investasi tinggi tetapi terhambat oleh pelayanan infrastruktur.

Menurut Pakdeenurit et al (2017), European Comission (2017), Chander (2012) yang berpendapat bahwa wilayah terbelakang adalah wilayah dengan perekonomian yang rendah, sumberdaya yang tertinggal, kelengkapan infrastruktur yang belum memadai, kemampuan keuangan daerah yang rendah, dan aksesibilitas yang sulit. Berdasarkan hasil penelitian yang telah dilakukan wilayah terbelakang adalah wilayah yang memiliki nilai alokasi investasi yang rendah, karakterfisik yang kurang mendukung, dan potensi wilayah yang rendah. Sehingga wilayah terbelakang adalah wilayah yang dipandang kekurangan dari segala aspek.

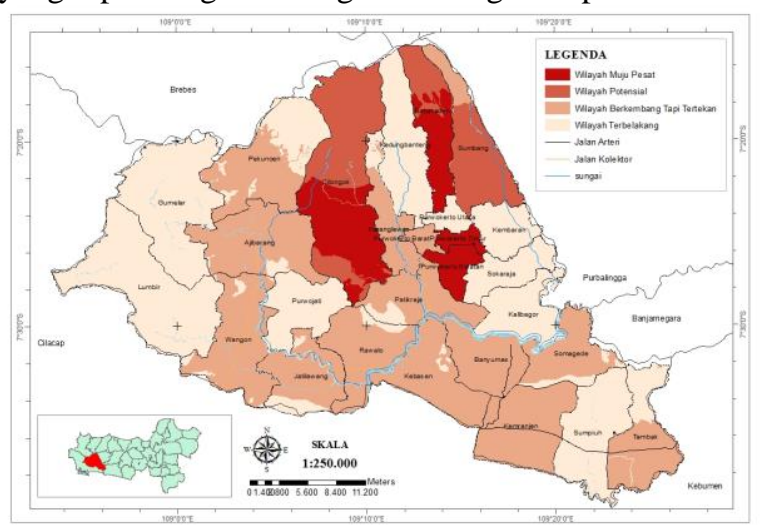

Gambar 5. Peta Tipologi Wilayah Investasi

\section{B. Kajian Pemberian jenis dan bentuk Insentif dan Kemudahan Penanam modal}

Kajian ini dilakukan dari hasil olahan data menggunakan alat analisis Analitycal Hierarchy Process berdasarkan tipologi wilayah yang telah di analisis sebelumnya.berikut merupakan hasil penelitian ini:

1. Wilayah Maju Pesat

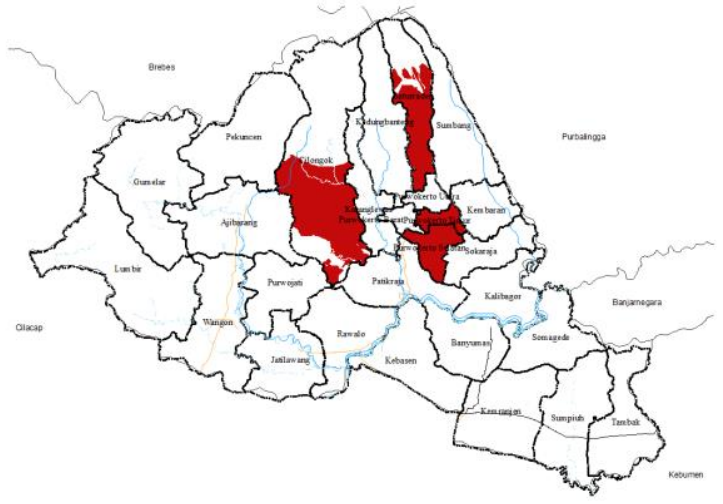

Gambar 6. Peta Tipologi Wilayah Maju Pesat
Wilayah maju pesat merupakan wilayah dengan nilai parameter fisik dan nilai alokasi investasi yang masuk sangat tinggi. Terlihat pada peta tipologi wilayah dibawah ini sebaran wilayah maju pesat untuk kegiatan investasi Kabupaten Banyumas adalah berada di Perkotaan Purwokerto, sebagian Kecamatan Cilongok, dan Kecamatan Baturaden. Wilayah ini memiliki karakteristik perdagangan dan jasa serta industry dalam pengembangan wilayahnya.

Tabel 5.

Prioritas Kriteria di Wilayah Maju

\begin{tabular}{lc}
\hline \multicolumn{1}{c}{ Kriteria } & Prioritas Global \\
\hline Parameter Fisik & 0,136 \\
Alokasi Investasi & 0,304 \\
Pelayanan Pemerintah & $\mathbf{0 , 5 6 1}$ \\
Inconsistency & 0,07 \\
\hline
\end{tabular}

Dari tabel diatas diketahui bahwa kriteria Pelayanan Pemerintah berbobot yang paling besar di antara kriteria lain, yaitu 0,561. Pelayanan pemerintah menjadi prioritas kriteria pada wilayah maju yang diajukan menurut expert yang dapat meningkatkan pemerataan pembangunan serta iklim investasi di Kabupaten Banyumas.

Tabel 6. Prioritas Alternatif di Wilayah Maju

\begin{tabular}{lc}
\hline \multicolumn{1}{c}{ Alternatif } & $\begin{array}{c}\text { Prioritas } \\
\text { Global }\end{array}$ \\
\hline Bantuan Pengembangan Riset Dan Pelatihan & 0,136 \\
Bantuan Penyediaan Sarana dan Prasarana & 0,159 \\
Bantuan Keuangan & 0,182 \\
Fasilitas Lahan atau Lokasi & 0,153 \\
Kemudahan Akses Pelayanan & $\mathbf{0 , 3 1 8}$ \\
Publikasi dan Promosi & 0,074 \\
Inconsistency & 0.07 \\
\hline
\end{tabular}

Hasil olahan data yang diperoleh yang menyatakan kemudahan akses pelayanan sebagai bentuk atau cara dalam pemerataan pembangunan dan peningkatan iklim investasi selaras dengan kajian literatur penelitian. Tatiana et al (2019) yang menyebutkan bahwa kemudahan akses perizinan kurang berpengaruh dalam peningkatan iklim investasi, selain itu parameter tersebut menjadi sangat penting bagi pengembangan wilayah andalan. Hal ini disebabkan karena aspek kemudahan akses perizinan menjadi tolak ukur utama dalam pengaturan kegiatan penanaman modal. Selain itu wilayah andalan tidak terlalu membutuhkan dorongan dari aspek penyediaan sarana dan prasarana atau bantuan pemasaran. Sehingga hal yang paling diperlukan dalam meningkatkan iklim investasi di wilayah andalan adalah kemudahan akses perizinan.

Kemudahan akses pelayanan yang dimaksudkan disini adalah lebih mengarah pada penyederhanaan dan percepatan perizinan, penyediaan data dan informasi peluang investasi, serta kemudahan proses pengadaan sertifikasi dan penerapan standar yang sesuai undang-undang. Selain itu juga apabila dikaitkan dengan potensi, klasifikasi wilayah maju lebih cocok menerapkan kemudahan akses pelayanan. Hal ini dikarenakan wilayah maju sudah memiliki dukungan dari ketersediaan 
infrastruktur yang lengkap, sumberdaya yang mendukung, serta aktivitas penanaman modal yang tinggi.

\section{Wilayah Potensial}

Berdasarkan hasil analisis tipologi wilayah investasi Kabupaten Banyumas, wilayah potensial merupakan wilayah dengan nilai parameter fisik tinggi namun nilai alokasi investasi yang cenderung rendah. Menurut hasil pengolahan peta wilayah potensial berada di Kecamatan Cilogok bagian utara dan selatan, Kecamatan Baturaden bagian utara, dan Kecamatan Sumbang.

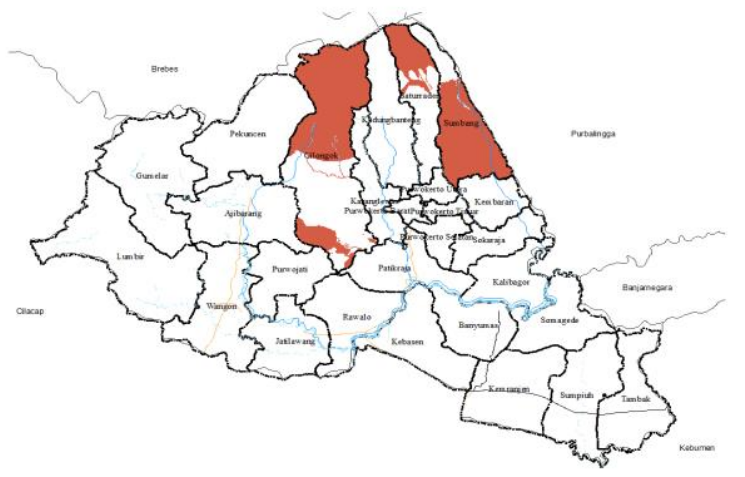

Gambar 7. Peta Tipologi Wilayah Potensial

Dari tabel dibawah diketahui bahwa kriteria alokasi investasi berbobot 0,662 . Bobot ini nilainya cukup signifikan jika kita bandingkan dengan kriteria lainnya. Hal ini berarti alokasi investasi menjadi prioritas jenis dan bentuk insentif dan upaya memudahkan aktivitas penanaman modal daerah yang dipilih oleh pemberi kebijakan untuk meningkatkan iklim investasi dan pemerataan pembangunan di wilayah potensial.

Tabel 7.

Prioritas Kriteria di Wilayah Potensial

\begin{tabular}{lc}
\hline \multicolumn{1}{c}{ Kriteria } & Prioritas Global \\
\hline Parameter Fisik & 0,137 \\
Alokasi Investasi & $\mathbf{0 , 6 6 2}$ \\
Pelayanan Pemerintah & 0,201 \\
Inconsistency & 0,06 \\
\hline
\end{tabular}

Berdasarkan nilai prioritas global yang diperlihatkan tabel di bawah ini untuk alternatif bentuk insentif dan kemudahan penanaman modal di wilayah potensial adalah bantuan keuangan dengan nilai eigen vector 0,222 . Hal ini berarti dari pengambilan keputusan oleh pemberi kebijakan dan penerima kebijakan telah sepakat memilih alternatif bantuan keuangan sebagai cara dalam peningkatan iklim investasi dan pemerataan pembangunan di klasifikasi wilayah potensial.

Berdasarkan tinjauan kebijakan terhadap variasi bentuk insentif dan kemudahan bantuan keuangan yang dimaksudkan adalah mengarah kepada pemberian keringanan, pengurangan, dan atau pembebasan pajak maupun retribusi daerah. Selain didasarkan pada tinjauan kebijakan, pertimbangan lain yang dapat menjadi acuan adalah potensi wilayah dan dominasi bidang usaha. Wilayah potensial memiliki bidang usaha dominan yaitu pengolahan sumber daya alam (pariwisata) dan industri. Sehingga bentuk insentif dan kemudahan yang tepat di wilayah ini adalah pemberian pengurangan, keringanan atau pembebasan pajak daerah maupun retribusi daerah.
Prioritas Alternatif di Wilayah Potensial

\begin{tabular}{lc}
\hline \multicolumn{1}{c}{ Alternatif } & Prioritas Global \\
\hline Bantuan Pengembangan Riset Dan Pelatihan & 0,114 \\
Bantuan Penyediaan Sarana dan Prasarana & 0,167 \\
Bantuan Keuangan & $\mathbf{0 , 2 2 2}$ \\
Fasilitas Lahan atau Lokasi & 0,209 \\
Kemudahan Akses Pelayanan & 0,179 \\
Publikasi dan Promosi & 0,107 \\
& \\
Inconsistency & 0,07 \\
\hline
\end{tabular}

\section{Wilayah Berkembang}

Berdasarkan hasil analisis tipologi wilayah investasi, wilayah berkembang tapi tertekan adalah wilayah dengan nilai parameter fisik rendah tetapi nilai alokasi investasi yang tinggi. Berdasarkan peta yang telah dihasilkan sebaran wilayah berkembang ini berada di Kecamatan Pekuncen, Kecamatan Ajibarang, Kecamatan Wangon, Kecamatan Jatilawang, Kecamatan Rawalo, Kecamatan Patikraja, Kecamatan Kebasen, Kecamatan Kemranjen, Kecamatan Banyumas, Kecamatan Karanglewas, Kecamatan Purwokerto Barat, Kecamatan Kebasen, Kecamatan Somogede, bagian utara Kecamatan Sumbang dan Kecamatan Tambak.

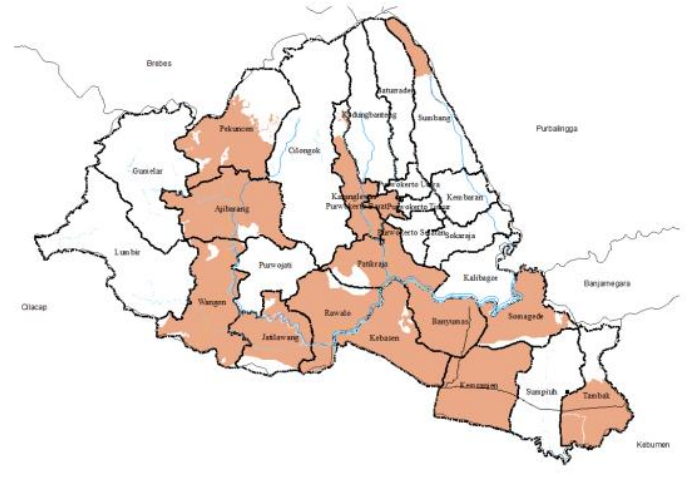

Gambar 8. Peta Tipologi Wilayah Berkembang

Tabel dibawah ini bahwa kriteria Parameter fisik memiliki bobot tertinggi yaitu 0,497 . Perbedaan bobot kriteria tertinggi dengan kriteria yang lainnya memiliki perbedaan yang cukup signifikasi. Parameter fisik menjadi prioritas kriteria yang dinilai oleh pemberi kebijakan di wilayah berkembang dalam pemilihan jenis dan bentuk insentif dan kemudahan penanaman modal Kabupaten Banyumas.

Tabel 9.

Prioritas Kriteria di Wilayah Berkembang

\begin{tabular}{lc}
\hline \multicolumn{1}{c}{ Kriteria } & Prioritas Global \\
\hline Parameter Fisik & $\mathbf{0 , 4 9 7}$ \\
Alokasi Investasi & 0,326 \\
Pelayanan Pemerintah & 0,176 \\
Inconsistency & 0,05 \\
\hline
\end{tabular}

Tabel 10.

Prioritas Alternatif di Wilayah Berkembang

\begin{tabular}{lc}
\hline \multicolumn{1}{c}{ Alternatif } & Prioritas Global \\
\hline Bantuan Pengembangan Riset Dan Pelatihan & 0,090 \\
Bantuan Penyediaan Sarana dan Prasarana & $\mathbf{0 , 2 1 2}$ \\
Bantuan Keuangan & 0,207 \\
Fasilitas Lahan atau Lokasi & 0,194 \\
Kemudahan Akses Pelayanan & 0,188 \\
Publikasi dan Promosi & 0,107
\end{tabular}




\begin{tabular}{ll}
\hline Kemudahan Akses Pelayanan & 0,173 \\
Publikasi dan Promosi & 0,109 \\
& \\
Inconsistency & 0,07 \\
\hline
\end{tabular}

\section{Wilayah Terbelakang}

Berdasarkan hasil analisis wilayah terbelakang merupakan wilayah dengan nilai parameter fisik dan nilai alokasi investasi sangat rendah. Wilayah terbelakang tersebar di Kecamatan Lumbir, Kecamatan Gumelar, Kecamatan Purwojati, bagian timur laut Kecamatan Pekuncen, Kecamatan Kedungbanteng, Kecamatan Kembaran, Kecamatan Sokaraja, Kecamatan Kalibagor, Kecamatan Sumpiuh, dan bagian utara Kecamatan Tambak.

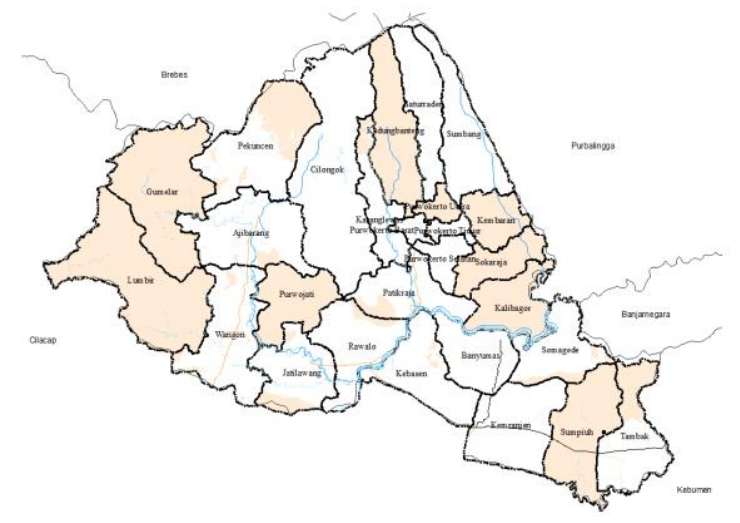

Gambar 9. Peta Tipologi Wilayah Terbelakang

Menurut data tabel dibawah diketahui bahwa bobot pada kriteria alokasi investasi adalah 0,749 yang bermakna kriteria ini cukup signifikan dibandingkan dengan kriteria lainnya. Alokasi investasi menjadi prioritas kriteria pilihan jenis dan bentuk insentif dan memudahkan penanaman modal di kawasan terbelakang yang diajukan oleh para expert. Nilai inkonsistensi data diatas adalah 0,04 yang menandakan jawaban para expert dianggap konsisten karena derajat inkonsistensinya lebih rendah dari $10 \%$.

Tabel 11.

Prioritas Kriteria di Wilayah Terbelakang

\begin{tabular}{lc}
\hline \multicolumn{1}{c}{ Kriteria } & Prioritas Global \\
\hline Parameter Fisik & 0,130 \\
Alokasi Investasi & $\mathbf{0 , 7 4 9}$ \\
Pelayanan Pemerintah & 0,115 \\
& \\
Inconsistency & 0,04 \\
\hline
\end{tabular}

Berdasarkan tabel di bawah memperlihatkan bahwa jawaban yang diberikan oleh para expert untuk wilayah terbelakang adalah bantuan keuangan dengan nilai eigen vector 0,209 . Nilai inkonsistensi global wilayah terbelakang adalah 0,07 , hal ini menandakan jawaban yang diberikan oleh para expert adalah konsisten.

Tabel 12.

Prioritas Alternatif di Wilayah Terbelakang

\begin{tabular}{|c|c|c|}
\hline Alternatif & & Pioritas Global \\
\hline $\begin{array}{l}\text { Bantuan Pengembangan Riset } \\
\text { Pelatihan }\end{array}$ & Dan & 0,103 \\
\hline $\begin{array}{l}\text { Bantuan Penyediaan Sarana } \\
\text { Prasarana }\end{array}$ & dan & 0,164 \\
\hline Bantuan Keuangan & & 0,209 \\
\hline Fasilitas Lahan atau Lokasi & & 0,204 \\
\hline
\end{tabular}

\section{KESIMPULAN DAN REKOMENDASI}

Penelitian ini memperoleh beberapa kesimpulan, berikut adalah paparannya:

1) Jenis insentif pada penelitian ini adalah usaha atau kegiatan investasi yang didasarkan pada spesifikasi wilayah. Terdapat 4 klasifikasi wilayah investasi yaitu maju, potensial, berkembang dan terbelakang.

2) Bentuk insentif dan kemudahan yang tepat diterapkan di wilayah maju adalah kemudahan akses pelayanan. Kemudahan akses palayanan yang dimaksudkan disini adalah lebih mengarah pada penyederhanaan dan percepatan perizinan, penyediaan data dan informasi peluang investasi, serta memudahkan sertifikasi dan penerapan standar sesuai undang-undang.

3) Bentuk insentif dan kemudahan yang tepat diterapkan di wilayah potensial adalah bantuan keuangan. Berdasarkan tinjauan kebijakan tehadap variasi bentuk insentif dan kemudahan bantuan keuangan yang dimaksudkan adalah mengarah kepada pemberian pengurangan, keringanan, atau pembebasan pajak daerah maupun retribusi daerah. Wilayah potensial memiliki bidang usaha dominan yaitu pengolahan sumberdaya alam (pariwisata) dan industri.

4) Bantuan sarana dan prasarana merupakan bentuk insentif dan yang memudahkan sehingga cocok diterapkan di wilayah berkembang. Hal ini disebabkan oleh banyaknya perusahaan yang masuk akan menghambat pelayanan sarana dan prasarana yang telah ada.

5) Bantuan keuangan merupakan bentuk bentuk insentif dan kemudahan yang cocok diterapkan di wilayah terbelakang. Bantuan Keuangan disini berbeda dengan wilayah potensial. Pada wilayah terbelakang mengarah kepada bunga pinjaman rendah, pemberian kompensasi, dan bantuan fasilitas usaha mikro, kecil, atau koperasi. Hal ini dikarenakan wilayah terbelakang memiliki bidang usaha dominan adalah pertanian, peternakan dan UMKM pengolahan makanan. Sehingga bentuk insentif dan kemudahan yang tepat di wilayah ini adalah mengarah pada bantuan pelatihan keterampilan dan bantuan pinjaman.

Berdasarkan hasil kesimpulan penelitian pada bab penutup ini, yang menyatakan bahwa jenis dan bentuk insentif dan kemudahan penanaman modal Kabupaten Banyumas adalah usaha yang didasarkan pada spesifikasi lokasi. Maka penelitian ini juga memberikan rekomendasi yang berguna untuk analisis AHP tentang Kajian Pemberian Jenis dan Bentuk Insentif Pada Sasaran Wilayah Investasi pada suatu wilayah di masa yang akan datang. Berikut merupakan beberapa rekomendasi yang dihasilkan:

1) Penelitian lebih lanjut pada pengelompokan jenis dan bentuk insentif serta kemudahan penanaman modal karena dimungkinkan adanya perubahan kebijakan terkait insentif 
dan kemudahan penanaman modal di masa yang akan datang.

2) Eksplorasi lebih lanjut terkait topik Jurnal yang mengkaji penggabuangan analisis pengembangan wilayah dan analisis insentif dan kemudahan penanaman modal.

3) Peneliti selanjutnya perlu mempertimbangkan fenomena PDRB Kabupaten Banyumas sudah dikatakan tinggi. Apakah masih perlu PMA masuk dalam kegiatan investasi, sedangkan tanpa modal asing kegiatan investasi Banyumas masih bisa berjalan. Apabila masih memerlukan PMA, dalam bentuk apa dan bagaimana?

4) Pemerintah Daerah harus lebih memperhatikan wilayah dengan perkembangan rendah, hal ini dikarenakan untuk tercapainya pemerataan pembangunan dan peningkatan iklim investasi. Pemerintah daerah dapat merealisasikan hal tersebut dengan membuat kebijakan pemberian insentif dan memperbanyak bentuk dan jenis insentif yang diwarkan. Sehingga minat investor dalam mendirikan usaha meningkat.

5) Pemerintah Daerah yang turun langsung mengurusi masalah investasi dan kebijakan insentif dan kemudahan penanaman modal, dalam hal pemberian pelayanan perizinan dan non perizinan belum berjalan maksimal. Hal ini dikarenakan lambatnya proses perizinan, yang mengakibatkan terhambatnya kegiatan penanaman modal. Sehingga perlu dilakukan evaluasi dalam hal proses perizinan.

6) Pemberian jenis dan bentuk insentif serta kemudahan penanaman modal masih minim, hal ini memperngaruhi minat investor. Sehingga tujuan dari pemberian insentif dan kemudahan untuk meningkatkan minat investor dalam menanamkan modalnya belum tercapai secara maksimal. Oleh karena itu Pemerintah Daerah perlu melakukan pengkajian ulang terkait kebijakan pemberian insenrif dan kemudahan agar tujuan yang direncanakan dapat terealisasi.

\section{DAFTAR PUSTAKA}

[1] Areas, P., Corridor, E., \& Areas, L. D. (2015). Less Developed Areas Incentive : Towards a state of equality.

[2] Belascu, L., \& Horobet, A. (2015). Foreign Direct Investments and Institutional Performance: a Romanian Perspective. Bulletin of Taras Shevchenko National University of Kyiv Economics, (174), 21-26. https://doi.org/10.17721/1728-2667.2015/174-9/3

[3] Chander, H. (2012). American Economic Association Trade and Investment in Underdeveloped Areas: A Comment Author ( $s): A . N$. McLeod Source: The American Economic Review, Vol . 41, No . 3 ( Jun ., 1951 ), pp . 411-419 Published by: American Economic Association Stable. 41(3), 411-419.

[4] Commander, S., \& Nikoloski, Z. (2011). Institutions and Economic Performance: What Can Be Explained? Review of Economics and Institutions, 2(2), 1-32. https://doi.org/10.5202/rei.v2i2.33

[5] Condly, S. J., Clark, R. E., \& Stolovitch, H. D. (2008). The Effects of Incentives on Workplace Performance: A Meta-analytic Review of Research Studies 1. Performance Improvement Quarterly, 16(3), 4663.

[6] https://doi.org/10.1111/j.1937-8327.2003.tb00287.x

[7] Dianta, A. (2015). Effect Invesment and The Rate of Inflation to Economic Growth in Indonesia. 14(1), 87-95.

[8] Eka Raswita, N., \& Utama, M. (2013). Analisis Pertumbuhan Ekonomi dan Ketimpangan Pendapatan Antar Kecamatan di Kabupaten Gianyar. E-Jurnal Ekonomi Pembangunan Universitas Udayana, 2(3), 119128.
[9] EUROPEAN COMISSION. (2017). Competitiveness in low-income and low-growth regions. 56.

[10] Fauziana, L., Mulyaningsih, A., Anggraeni, E., M, S. C. Y., \& Rofida, U. (2014). Keterkaitan Investasi Modal Terhadap Gdp Indonesia. Economics Development Analysis Journal, 3(2), 372-380. https://doi.org/10.15294/edaj.v3i2.3845

[11] Harker, P. T. (2000). Performance of Financial. Cambridge University Press, 45(9).

[12] IMF. (2015). Options for Low Income Countries' Effective and Efficient Use of Tax Incentives for Investment. Options for Low Income Countries' Effective and Efficient Use of Tax Incentives for Investment, (October). https://doi.org/10.1596/22924

[13] Kachu, R. (2002). Impact of Special Economic Zones on Regional. 59.

[14] Kurniawan, Y. A. (2009). PRIORITAS PEMILIHAN PROYEK TRANSMISI SDH MENGGUNAKAN METODE AHP \& EXPERT CHOICE (Studi Kasus: PT. ZTE Indonesia).

[15] Gaussan, Lq. Sektor, P., Potensi, D. A. N., \& Kota, D. I. (2018). $L q$, Mrp and Klassen Analysis To Determine Leading and. (November). https://doi.org/10.13140/RG.2.2.36817.79203

[16] Malinda, O., Dewi, F. G., \& Gamayuni, R. R. (2019). The Effect of Incentives and Non-Financial Performance on Managerial Performance. 12(1), 41-54.

[17] McNamara, K. T., \& Green, G. P. (2008). Local and Regional Economic Development Planning and the Role of Community Development Practitioners. Community Development Society. Journal, 19(2), 42-55. https://doi.org/10.1080/15575338809490004

[18] Munandar, A. (2010). PENGEMBANGAN WILAYAH Oleh: ARIS MUNANDAR.

[19] Nasir, A. (2004). ANALISIS EFEKTIVITAS PEMBERIAN INSENTIF FISKAL DI KAWASAN TIMUR INDONESIA ( KTI ) ( STUDI KASUS: KAPET PARE PARE ). Analisis Efektivitas Pemberian Insentif Fiskal, 8(1), 1-18.

[20] Pakdeenurit, P., Member, N. S., \& Rattanawong, W. (2017). Special Economic Zone: Facts, Roles, and Opportunities of Investment. (March 2014).

[21] Pezzey, J. J. (2015). An Economic Analysis.

[22] Pindyck, R., \& Rubinfeld, D. (2013). Microeconomia.

[23] Rademaekers, K., Williams, R., Ellis, R., Smith, M., Svatikova, K., \& Bilsen, V. (2012). Study on incentives driving improvement of environmental performance of companies. (May). Retrieved from http://bibliotecavirtual.minam.gob.pe:8080/biam/handle/minam/1642

[24] Rahayu, E. S. (2010). Pengembangan Sub Sektor Pertanian Tanaman. Journal of Rural and Development, I(2).

[25] Reza, T., Hamed, A., \& Amaneh, H. (2011). Analyzing performance of investment companies listed in the Tehran stock exchange by selected ratios and measures. African Journal of Business Management, 5(17), 7428-7439. https://doi.org/10.5897/ajbm11.204

[26] Sasongko, A., Astuti, I. F., \& Maharani, S. (2017). Pemilihan Karyawan Baru Dengan Metode AHP (Analytic Hierarchy Process). Informatika Mulawarman: Jurnal Ilmiah Ilmu Komputer, 12(2), 88. https://doi.org/10.30872/jim.v12i2.650

[27] Series, I. A. (2008). Investment Advisory Series Series A, number 3 United Nations Conference on Trade and Development EVALUATING INVESTMENT PROMOTION AGENCIES United Nations New York and Geneva 2008. (3). Retrieved from http://www.unctad.org.

[28] Ślusarczyk, B. (2018). Tax incentives as a main factor to attract foreign direct investments in Poland. Administratie Si Management Public, 2018(30), 67-81. https://doi.org/10.24818/amp/2018.30-05

[29] Sugiyono. (2013). Metode Penelitian Manajemen (I; Setiyawami, ed.). Bandung: Alfabeta.

[30] Sun, W., Lin, X., Liang, Y., \& Li, L. (2016). Regional inequality in underdeveloped areas: A case study of Guizhou province in China. Sustainability (Switzerland), 8(11). https://doi.org/10.3390/su8111141

[31] Supartoyo, Y. H., Tatuh, J., \& Sendouw, R. H. E. (2014). The Economic Growth and the Regional Characteristics: The Case of Indonesia. Buletin Ekonomi Moneter Dan Perbankan, 16(1), 3-18.

[32] https://doi.org/10.21098/bemp.v16i1.435

[33] Syaifullah. (2010). Pengenalan Metode AHP ( Analytical Hierarchy Process ). Wordpress, $1-11$.

[34] Tatiana, Y., Firdaus, M., Siregar, H., Tatiana, Y., Analisis, D. K. K., Pembangunan, P., \& Bengkulu, P. (2019). Analisis Perwilayahan Pembangunan dan Iklim Investasi di Provinsi Bengkulu. 31(2), 295- 
306.

[35] Thomas, K. P. (2007). Investment Incentives: Growing use, uncertain benefits, uneven controls. Retrieved from:

[36] https://www.iisd.org/gsi/sites/default/files/GSI_Investment_Incentives.p df

[37] Tykkyläinen, M., Hyttinen, P., \& Mononen, A. (1997). Theories of Regional Development and Their Relevance to the Forest Sector. 31(4), 447-459.

[38] Ustinovichius, L., Komarovska, A., \& Komarovski, R. (2017). Methods of Determining the Region's Investment Strategy. Procedia Engineering, $\quad$ 182, 732-738. https://doi.org/10.1016/j.proeng.2017.03.190

[39] Wilonoyudho, S. (1993). Kesenjangan dalam pembangunan kewilayahan. 167-180. 